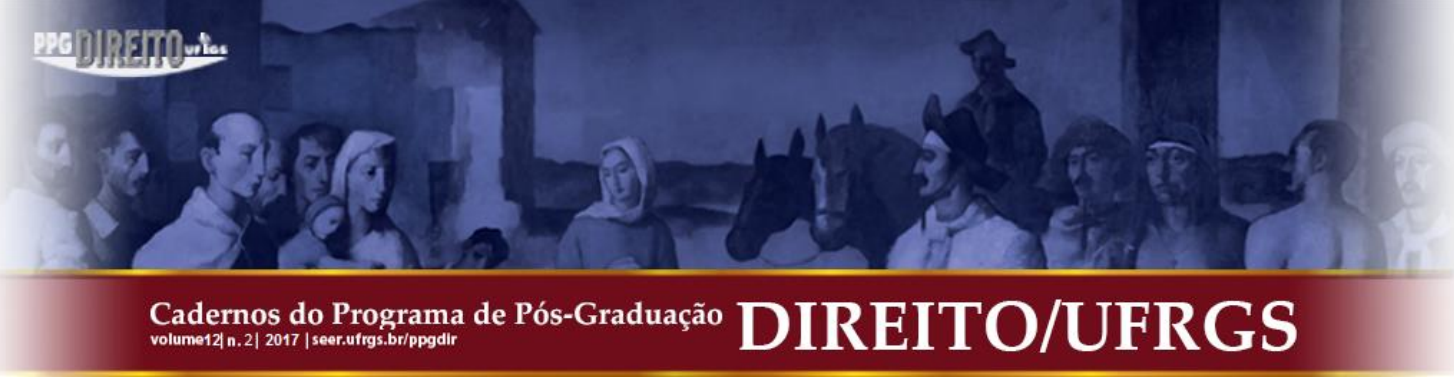

\title{
A PARTICIPAÇÃO DA SOCIEDADE CIVIL NA ESCOLHA DOS MINISTROS DO SUPREMO TRIBUNAL FEDERAL
}

\author{
CIVIL SOCIETY PARTICIPATION IN THE SELECTION OF SUPREME COURT JUDGES
}

Eduardo Silva Luz*

José Eduardo Sabo Paes**

\begin{abstract}
RESUMO: O presente artigo possuí a precípua missão de analisar o atual procedimento de escolha dos integrantes do Supremo Tribunal Federal, realizando um estudo aprofundado quanto aos critérios estabelecidos no texto constitucional, que devem ser obedecidos pelo chefe do executivo, quando da indicação do Ministro da Corte Constitucional. Ademais, será analisado se é possível à participação direta da sociedade civil nesse processo de indicação do membro da Corte, com a finalidade de termos processo mais democrático e transparente. A metodologia utilizada para a consecução dos objetivos citados será revisão bibliográfica de textos brasileiros e latino-americanos, que realizam estudos quanto a cortes constitucionais e jurisdição constitucional, aliado a isto utilizaremos o método comparado para analisar o procedimento de escolha dos membros dos tribunais superiores em outros países da América Latina. Ao final do artigo pretende-se oferecer propostas para uma maior democratização do processo de escolha dos membros do STF de forma a propiciar a participação da sociedade civil neste processo.
\end{abstract}

PALAVRAS-CHAVE: Escolha. Supremo Tribunal Federal. Sociedade Civil. Ministros. nas Constituições. 1.2 Critérios Abertos. 2 Sociedade Civil no Brasil. 3 Análise Comparada. 3.1 Argentina. 3.2 Bolívia. 3.3 Chile. 4 A Possibilidade da Participação da Sociedade Civil na Composição do Supremo Tribunal Federal. Considerações Finais. Referências.

\section{INTRODUÇÃo}

Quando tratamos de justiça constitucional no Brasil, principalmente há quem deve caber a guarda da Constituição, a resposta quase que imediata é que trata-se do Supremo Tribunal Federal, que recebeu competência material e formal, para julgar as questões que tenham como escopo à proteção do texto constitucional, com isso torna-se óbvio, repetir diversas vezes que o guardião da carta magna é o STF. Porém, no atual estágio democrático e de participação

\footnotetext{
* Mestrando em Direito pelo Programa de Pós-Graduação em Direito da Universidade Católica de Brasília (UCB), Distrito Federal. Pesquisador Bolsista CAPES. Editor-Assistente da Economic Analysis of Law Review.

** Doutor e Mestre em Direito pela Universidad Complutense de Madrid, Espanha. Professor Programa de PósGraduação em Direito da Universidade Católica de Brasília (UCB), Distrito Federal.
} 


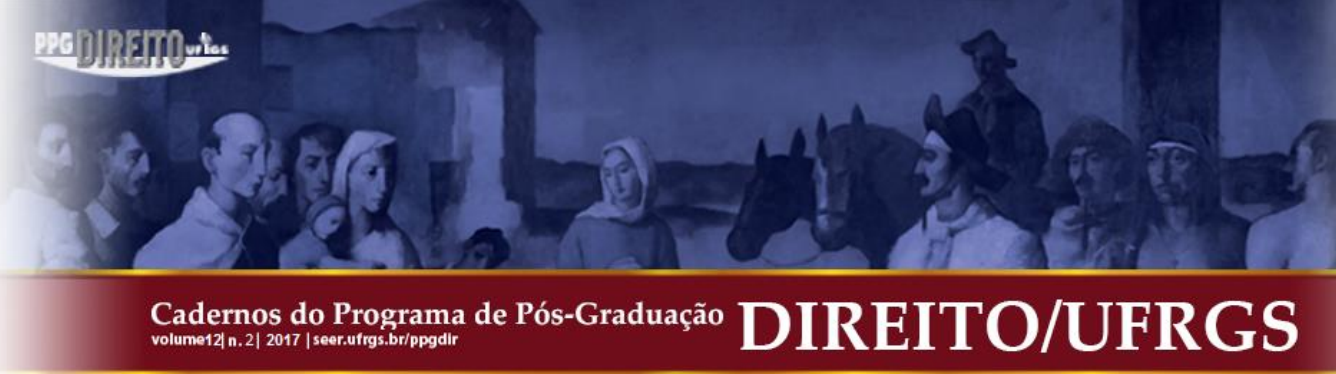

social, devemos ampliar essa interpretação e aprofundar a resposta para a pergunta, afirmando que não apenas o Supremo Tribunal Federal nem mesmo somente o Poder Legislativo, Poder Executivo e todo o Poder Judiciário, devem resguardar a constituição, mas a sociedade deve também ser uma guardiã do texto constitucional, protegendo seus direitos individuais e sociais, ou seja, trata-se de uma questão holística em que todos têm uma responsabilidade.

Vale, entretanto, ressaltar que este artigo não questiona a importância do Supremo Tribunal Federal, corte constitucional com tão valiosa finalidade, que lutou durante anos para consolidar sua posição na democracia brasileira, conseguindo sair da esfera de influência dos demais poderes, e se alçando a uma esfera de vanguarda, que para muitos autores é definido como um ativismo judicial. Entretanto, o que se pretende com esse artigo é embasar e consolidar o argumento de que a sociedade civil deve participar mais ativamente, no processo de defesa da Constituição, não sendo suficiente sua participação somente como amicus curie, ou seja, uma participação no decorrer do processo constitucional.

A indicação dos Ministros do Supremo Tribunal Federal tem uma grande relevância para a democracia brasileira em razão de que estes a todo momento durante o exercício de sua função irão se defrontar com questões políticas e de Estado, que gerará efeitos erga omnes em razão disso é bastante importante a organização da sociedade em grupos, pois primeiro demonstra uma maturidade institucional, e segundo uma melhor capacidade para participar do jogo democrático, pois dessa forma é capaz de ter sua voz ouvida com mais resplendência dentro da República.

Em razão disso que será explorado nesse artigo, a possibilidade da sociedade civil vir a participar efetivamente, direta ou indiretamente, do processo de escolha dos integrantes da Corte Constitucional, dessa forma, estar-se-ia valorizando os ideais de uma democracia mais participativa.

O sistema de escolha e nomeação dos Ministros do Supremo Tribunal Federal, atualmente trata-se de um processo que não condiz muito, com atual estágio democrático do Brasil, principalmente por se tratar totalmente de uma escolha discricionária pelo chefe do poder executivo, e que é envolto de acordos e negociações políticas, caracterizados por jogos de bastidores, em que a população fica excluída da participação, sem a possibilidade de opinar.

Desde a Constituição de 1891 a escolha dos Ministros do Supremo Tribunal Federal é feita exclusivamente pelo chefe do poder executivo, devendo o indicado passar por uma

Cadernos do Programa de Pós-Graduação em Direito PPGDir./UFRGS | Edição Digital | Porto Alegre | Volume XII | Número 2 | 2017 | P. 257 - 280 


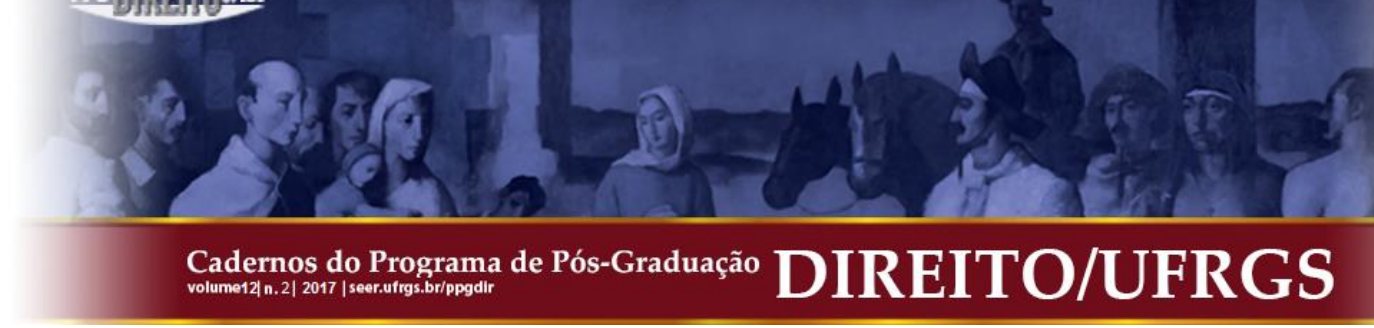

\section{O STF - EVOLUÇÃO HISTÓRICA E CRITÉRIOS DE SELEÇÃO}

O Supremo Tribunal Federal situa-se no ápice do Poder Judiciário, funcionando assim tanto como função de tribunal de matéria recursal (quando desta tiver referência à matéria constitucional), bem como guardião da constituição, exercendo assim o controle de constitucionalidade concentrado/abstrato, difuso/concreto.

A ideia de se ter uma Corte Constitucional, inserida dentro do Poder Judiciário, vem de uma inspiração do modelo norte-americano, em contraposição com o modelo de justiça constitucional europeu, em que a Corte Constitucional, que trata da defesa da Constituição, encontra-se fora da hierarquia do Poder Judiciário, para ressaltar, principalmente a tarefa política que é realizada pela corte, em razão de realizar um controle de normas frente a constituição.

Analisando de forma histórica, a criação do STF, somente irá ocorrer com a Carta de 1891, porém já no império, já havia uma embrionária ideia de transformar o Supremo Tribunal de Justiça (órgão que ocupava a hierarquia máxima do judiciário pela Constituição de 1824) em algo próximo do que seria a Suprema Corte Americana, em razão de que D. Pedro II, já idealizava transferir o seu poder moderador para essa futura Corte. (FIUZA, 2002, p.177)

Porém, apenas com a Proclamação da República, e com a edição do Decreto nº 848 de 11 de outubro de 1890, foi criado o Supremo Tribunal Federal, passando a ter respaldo constitucional, a partir da Constituição 1891, que tratava especificamente da matéria nos artigos 55 e 56, colocando o dentro do Poder Judiciário da União, com sede na Capital da República, sendo composto por 15 juízes.

Excetuando-se os casos de composição e forma de seleção dos juízes que compõe a corte, pouca coisa se alterou quanto ao Supremo Tribunal Federal, desde sua criação com a constituição de 1891, até a atual carta de 1988, excetua-se apenas a mudança de nomenclatura do Tribunal que ocorreu em 1934, quando a corte passa a se chamar Corte Suprema, o que for restabelecendo-se em 1937 a sua atual nomenclatura.

Porém, embora não tenha passado por grandes mudanças estruturais, o Supremo Tribunal Federal, por vezes no decorrer de sua história teve que passar por diversas mudanças de postura, com isso pode-se dizer que a história do STF, é recheada de momentos de avanços 


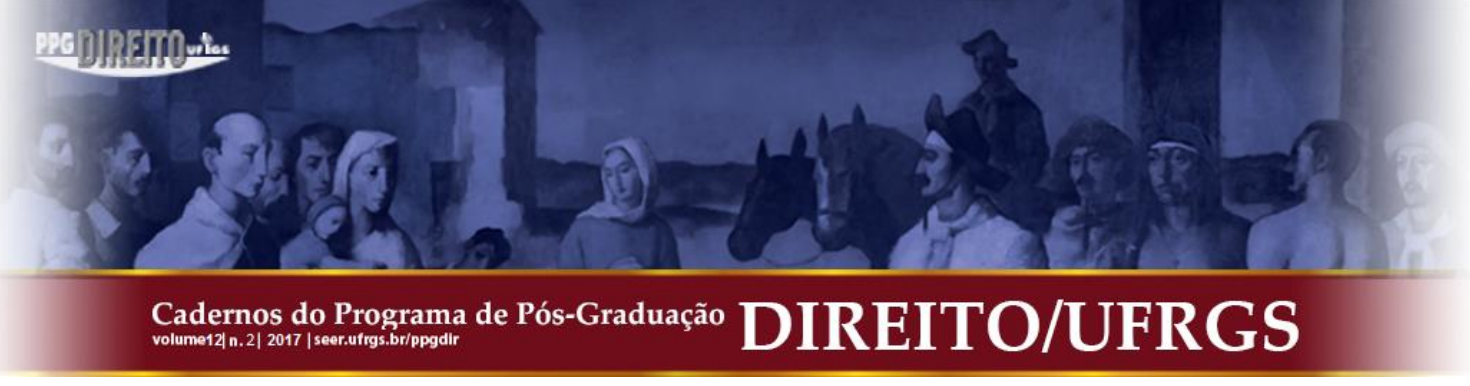

e recuos $^{2}$, bastante conectados com a questão política e atuação do Poder Executivo, invadindo a esfera de competência do tribunal.

A República em 1891 recentemente inaugurada vivia o auge do Poder Executivo, e tinha no Poder Judiciário apenas como um braço de extensão de sua atuação, por isso a dificuldade inicial do Supremo Tribunal Federal em julgar questões de Estado, e principalmente em garantir sua legitimidade e autonomia quanto as suas decisões. A esse respeito vale citar o eminente jurista Oliveira Viana, que à época já retratava necessidade de um Poder Judiciário e forte dissociado do poder executivo como forma de consolidação democrática:

\begin{abstract}
Os nossos reformadores constitucionais e s nossos sonhadores liberais ainda não se convenceram de que nem a generalização do sufrágio direto, nem o self-government valerão nada sem o primado do Poder Judiciário - sem que este Poder tenha pelo Brasil todo a penetração, a segurança, a acessibilidade que o ponha a toda hora e a todo momento ao alcance do jeca mais humilde e desamparado, não precisando ele para tê-lo junto a si de mais do que um gesto da sua mão numa petição ou de uma palavra de sua boca num apelo. Sufrágio direto ou sufrágio universal, regalias de autonomia, federalismos, municipalismos - de nada valerão sem este primado do Judiciário, sem a generalidade das garantias trazidas por ele à liberdade civil do cidadão, principalmente do homem-massa do interior - do homem dos campos, das vilas, dos povoados, das aldeias, das cidades, sempre anuladas nestas garantias pela distância dos centros metropolitanos da costa. De nada valerão a estes desamparados e relegados, entregues aos caprichos dos mandões locais, dos senhores das aldeias e dos delegados cheios de arbítrios, estas regalias políticas, desde que os eleitos por este sufrágio universal e direto - sejam funcionário municipais, sejam estaduais, pouco importa - estiverem certos que poderão descumprir a lei ou praticar a arbitrariedade impunemente. O ponto vital da democracia brasileira não está no sufrágio liberalizado a todo o mundo, repito; está na garantia efetiva do homem do povo-massa, campônio ou operário, contra o arbítrio dos que "estão de cima" - dos que detêm o poder, dos que "são-governo". Pouco importa, para a democracia no Brasil, sejam estas autoridades locais, eleitas diretamente pelo povo-massa ou nomeadas por investidura carismática: se elas forem efetivamente contidas e impedidas do arbítrio - a democracia estará realizada”. (SENADO FEDERAL, 1999).
\end{abstract}

Como se pode aferir, pela leitura da passagem, o Brasil, nos períodos iniciais da república, passava por um período de afirmação e consolidação democrática que estava intimamente conectado com o aumento da autonomia do Poder Judiciário, mais especificamente do Supremo Tribunal Federal, que teria a função precípua a guarda da constituição.

Essa autonomia do Poder Judiciário só irá se completar, com a Constituição Federal de 1988, que aumentou a competência os poderes do Supremo Tribunal Federal, e possibilitou

\footnotetext{
${ }^{2}$ Quando se coloca momento de "avanços e recuos", se quer retratar que durante todo o século XIX na América Latina vivia-se o esplendor do presidencialismo com o poder máximo na esfera do executivo, o poder judiciário restava-se dentro de sua esfera de influência servindo como forma de ratificação da atuação do executivo.

Cadernos do Programa de Pós-Graduação em Direito PPGDir./UFRGS | Edição Digital | Porto Alegre | Volume XII | Número 2 | 2017 | P. 257 - 280
} 


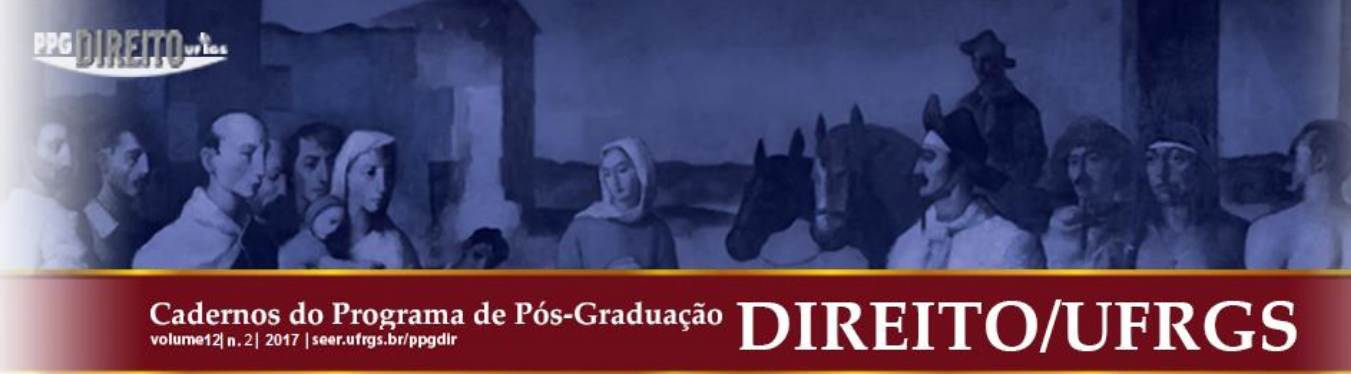

maior independência deste dos demais poderes, embora que de forma ainda precária, mas que possibilitou que os ministros pudessem decidir mais, sobre questões de Estado e direitos e garantias fundamentais.

\subsection{Nomeação dos Ministros do Supremo Tribunal Federal nas Constituições}

A Constituição de 1891 a primeira a tratar do STF, estabelecia-se em seu artigo 56 que o Supremo Tribunal Federal seria compostos por quinze juízes, nomeados pelo Presidente da República, dentre cidadãos de notável saber e reputação jurídica, elegíveis para o Senado (BRASIL, 1891). A primeira composição do Supremo teve uma característica de que a maioria dos membros tinha vindo do anterior Supremo Tribunal de Justiça. Com uma clara inspiração norte-americana, a escolha e nomeação foram colocadas entre as atribuições do chefe do executivo, tendo que após, haver a manifestação do Senado em caráter a posteriori, que ratificaria a nomeação do Ministro, por maioria simples.

A Constituição de 1934 realizou uma alteração de nomenclatura para Corte Suprema, bem como reduziu o número de quinze ministros, para onze, sendo que também possibilitou que a alteração do número de membros, poderia ser feito por lei, não necessitando de Emenda a Constituição, desde que se fosse aumentado ao máximo de dezesseis, mediante lei que deveria ser proposta pela própria Corte, segundo a inteligência do artigo 73 , daquela constituição. A Carta de 1934 é a primeira a estabelecer limite mínimo de trinta e cinco anos e máximo de sessenta e cinco anos (mesmo da aposentadoria compulsória) de idade para que o ministro pudesse ser investido no cargo.

Coube à Constituição de 1937, a volta do nome para Supremo Tribunal Federal, e se manteve os parâmetros que se estabeleceram nas constituições anteriores, com duas exceções, quanto a idade máxima que havia sido reduzida para 58 anos, e uma outra exceção para adequação ao regime do Estado Novo, na qual a deliberação passou a ser competência do Conselho Federal, órgão que substituía o Senado Federal.

A Constituição de 1946 portou-se bastante nostálgica, ao resgatar as características da primeira constituição da república, referentes ao Supremo Tribunal Federal, com alguns adendos, na qual os Ministros seriam nomeados pelo Presidente da República, depois de aprovada a escolha por maioria simples pelo Senado Federal, dentre brasileiros maiores de trinta 


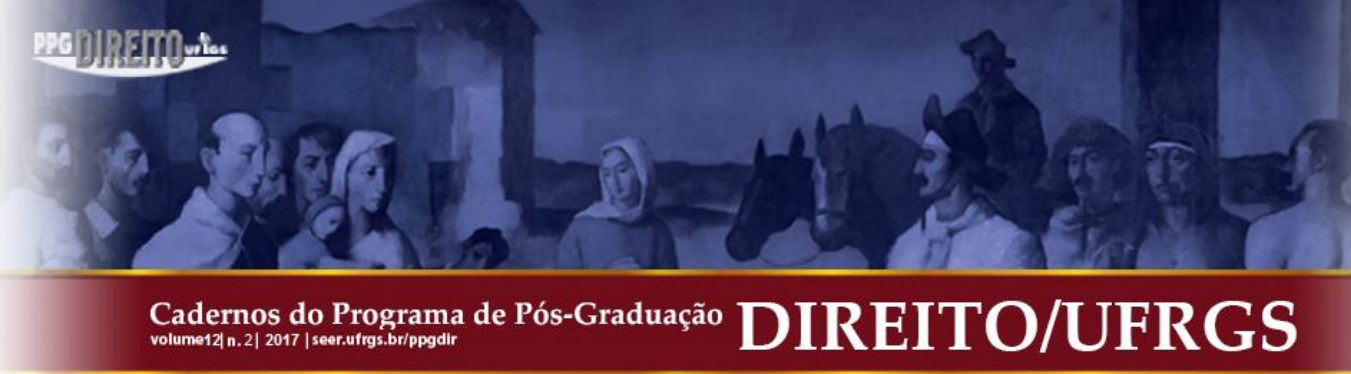

e cinco anos, de notável saber jurídico e reputação ilibada. Bem como estabeleceu o limite para aposentadoria compulsória em 70 anos, que viria persistir nas constituições seguintes até Emenda Constitucional 88/2015.

Na Constituição de 1967, o número de Ministros foi elevado de onze para dezesseis. Entretanto, essa foi a única mudança, manteve-se praticamente o mesmo modelo de escolha e nomeação definidos na carta de 1946, sistema esse que continuou sob égide da Emenda Constitucional $\mathrm{n}^{\mathrm{o}} 1$ de 1969, que para muitos se trataria de uma constituição propriamente dita, outorgada durante o regime militar.

A atual Constituição de 1988 dispõe que se comporá o Supremo Tribunal Federal de onze ministros, que devem ser escolhidos pelo Presidente da República, sendo que após o processo de escolha, serão submetidos a uma sabatina no senado federal, sendo nomeados após aprovação por maioria absoluta de votos, o que distingue o procedimento previsto nas constituições anteriores que necessitava de apenas maioria simples. A escolha deve ser feita entre os brasileiros natos, com mais de trinta e cinco e menos de sessenta e cinco anos de idade, de notável saber jurídico e reputação ilibada. Vale ressaltar o caráter vitalício garantido pela constituição aos Ministros do STF, com uma aposentadoria compulsória aos setenta e cinco anos de idade, regra prevista recentemente, por meio da $\mathrm{EC} \mathrm{n}$ n $^{\circ} 8 / 2015$.

Após essa digressão histórica, percebe-se que o processo de escolha e nomeação dos Ministros do STF, bem como os critérios a serem obedecidos, pouco evoluíram, desde a constituição de 1891, mantendo assim ainda, a velha inspiração norte-americana, e demonstrando uma estagnação quanto os ideais de democracia participativa, no momento em que deixa ao alvitre do chefe do executivo a escolha discricionária de um membro de uma instituição tão importante como o Supremo Tribunal Federal, para a consolidação dos preceitos democráticos no Brasil.

\subsection{Critérios Abertos}

Quando tratamos da nomeação dos Ministros do Supremo Tribunal Federal Brasileira, e analisamos os critérios e a forma como deve ocorrer segundo a Constituição de 1988, percebese em uma visão holística e genérica que deveria haver uma participação integrada do Poder 


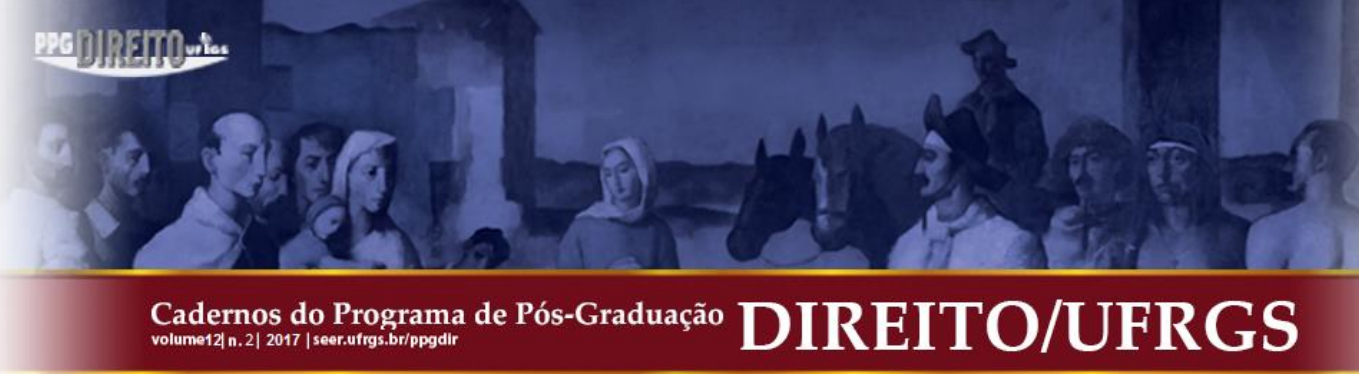

Executivo e do Legislativo, o que na teoria proporcionaria maior legitimidade democrática aos magistrados integrantes da excelsa corte.

$\mathrm{O}$ modelo de nomeação dos Ministros também estaria adequado à teoria dos freios e contrapesos, mecanismo que permite ao poder controle do poder, através de uma repartição de competência, que impediria concentração de poderes em cima de uma única autoridade do Estado. José Afonso da Silva, ao analisar a teoria do checks and balances, prescreve que esta tem como finalidade principal o equilíbrio voltado para o bem da coletividade e indispensável para impedir que um Poder se sobressaia de forma discricionária sobre os demais. (SILVA, 2004, p. 110)

É bastante razoável que a forma de investidura ao cargo de ministro da Corte Constitucional, seja feita de forma diferente, do processo de escolha dos magistrados da jurisdição ordinária, em razão de que o papel a ser exercido, pelo ministro, não estará restrito a questões jurídicas, mas estará envolto de questões políticas e de Estado, em razão disso fala-se em uma natureza jurídico-política do Supremo Tribunal Federal. Ademais sobre essa nomeação política, vale citar, o jurista francês Louis Favoreu:

(...) a designação de juízes constitucionais por autoridades políticas, segundo
motivação política, longe de constituir uma imperfeição dos sistemas de justiça
constitucional, é ao contrário, uma qualidade e mesmo uma necessidade: pois a
legitimidade da justiça constitucional repousa em grande parte sobre essa técnica de
designação, de tal modo que ela é hoje aceita de maneira geral”. (FAVOREU, 2004,
p. 233).

Com isso, é dado ao chefe do executivo, e ao senado federal, uma certa liberdade na escolha dos candidatos ao cargo, que deveriam não apenas possuir o saber jurídico e a reputação ilibada, requisitos constitucionais, mas também ter a habilidade saber julgar e relacionar com questões políticas que são advindas inerentes ao exercício do cargo, de magistrado da corte constitucional.

Pelo exposto, percebe-se que não é nenhuma anomalia jurídica, a participação e a escolha política, do candidato ao cargo de ministro do supremo, o que na verdade tem-se de tecer críticas é como esse modelo pouco evoluiu ou mesmo como foi importado de um modelo norte-americano de composição da Suprema Corte, sem que houvesse adaptações a realidade democrática do Brasil.

Há uma tendência tradicional e histórica no Brasil, de concentração dos poderes na mão do executivo, que chega a invadir a esfera de competência dos demais poderes. O que faz com 


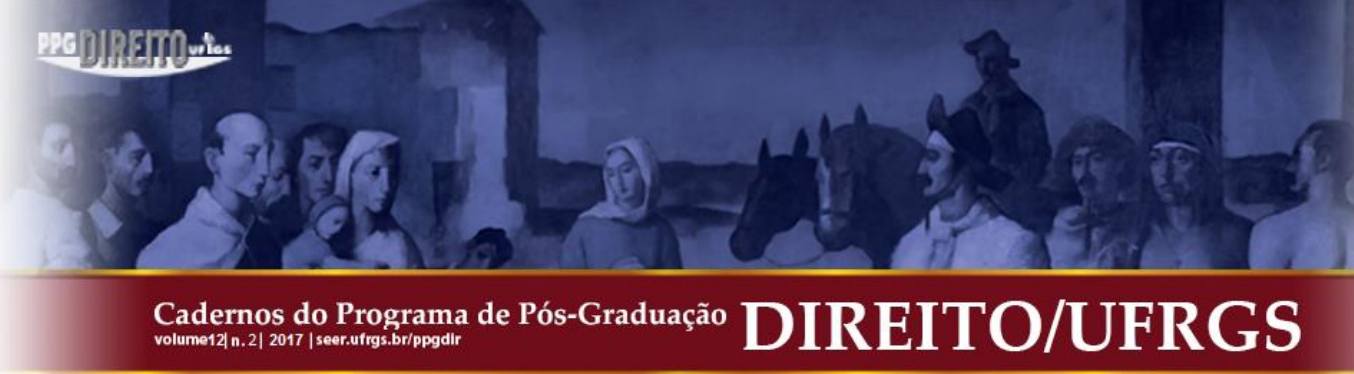

que a forma de composição da corte se torne um potencial fato gerador de crises jurídicopolíticas.

Atualmente, muito mais do que funcionar, como uma forma de freios e contrapesos, e de controle do poder pelo poder, a forma de nomeação do ministro do supremo, acaba concentrando toda a responsabilidade nas mãos do chefe do executivo caracterizando-se propriamente como uma escolha política e pessoal deste que exerce o poder no momento, em razão de que a segunda parte do processo, que seria a participação do senado federal, funciona atualmente como uma forma única e exclusiva de ratificação da escolha feita pelo presidente, tratando-se da clássica política de bastidores. ${ }^{3}$

Esse modelo acaba por não se adequar aos atuais estágios de democracia em que se anseia um maior diálogo entre os poderes e sociedade dentro das instituições dos Estado, como no caso em específico do Supremo Tribunal Federal.

Vale tecer críticas ao que os doutrinadores de direito constitucional, chamam de critérios objetivos a serem seguidos pelo chefe do executivo no momento da escolha do candidato ao cargo de ministro do Supremo Tribunal Federal, esses requisitos estão contidos no artigo 101 da CRFB que prescreve, "O Supremo Tribunal Federal compõe-se de onze Ministros, escolhidos dentre cidadãos com mais de trinta e cinco e menos de sessenta e cinco anos de idade, de notável saber jurídico e reputação ilibada.”

Os critérios de idade mínima e máxima, o notável saber jurídico e a reputação ilibada, são denominados pela doutrina como requisitos ou critérios objetivos que devem ser atendidos por parte do chefe do executivo durante o processo de indicação do Ministro do Supremo Tribunal Federal.

Analisando esses critérios sem entrar no mérito quanto questão de idade, gostar-se-ia aqui de defender a seguinte ideia, principalmente quanto ao caso do notável saber jurídico, esse requisito, está envolto de subjetividade, em razão de ser um conceito lato o que possibilitaria uma escolha totalmente discricionária.

\footnotetext{
3 O Jornal Folha de São Paulo realizou um estudo que confirma as afirmações acima, na qual todos os Ministros desde o processo de redemocratização, foram aprovados por unanimidade de votos dos Senadores. Sendo o Ministro Luiz Fux o com mais votos a favor (68 senadores), e o Ministro Luiz Edson Fachin com mais votos contrários (27 senadores), explicável a quantidade de votos contrário por ter sido indicado em um período de baixa popularidade e instabilidade política pelo chefe do executivo. Gráfico Disponível em: <http://www1.folha.uol.com.br/poder/2017/02/1860956-cinco-candidatos-ao-stf-ja-foram-rejeitados-pelo-
} senado-saiba-quando.shtml>. Acesso em: 20 mar. 2017.

Cadernos do Programa de Pós-Graduação em Direito PPGDir./UFRGS | Edição Digital | Porto Alegre | Volume XII | Número 2 | 2017 | P. 257 - 280 


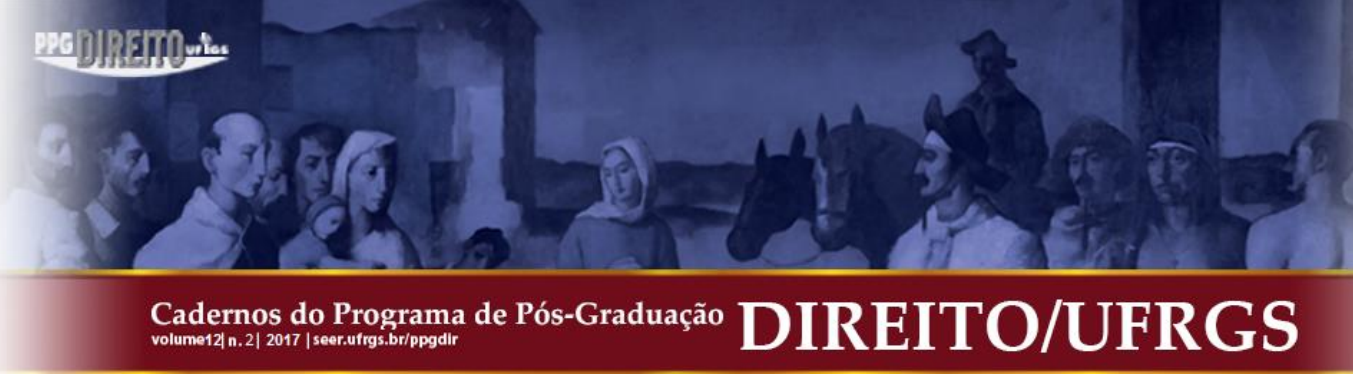

O primeiro conceito problemático, seria o notável saber jurídico, em um exercício mental bastante simples, se pode afirmar que não se torna necessário que o Ministro do STF, tenha uma formação jurídica de forma própria, ou seja, não seria necessário que o mesmo fosse graduado em direito, com isso não haveria limites acadêmicos mínimos para o exercício do cargo, bastando apenas o entendimento básico de direito.

Muito embora, essa abertura de forma holística é permitida por esse artigo da constituição, existe uma tradição política em indicar pessoas com graus acadêmicos e com uma carreira jurídica consolidada, para o cargo de Ministro do STF. Dentre os atuais membros do STF tem-se um total de 6 Doutores, 2 Mestres, e 3 Graduados em Direito.

O segundo conceito que também deixa bastante aberto é o caso de reputação ilibada, em razão que não é um exercício fácil deduzir o que se enquadraria como reputação ilibada, seria o mesmo critério para poder se candidatar a um cargo eletivo? Ou mesmo a ausência de antecedentes criminais?

Com essa dificuldade de entender a referida objetividade desses conceitos previstos na constituição, é que se argumenta a tese de que os mesmo seriam bastante subjetivos e interpretativos, deixando ampla margem para que o Chefe do Executivo possa escolher dentro de sua esfera de preferência pessoal de forma exclusiva, excluindo os demais poderes e a sociedade.

\section{SOCIEDADE CIVIL NO BRASIL}

Sem ter o intuito de fazer grandes digressões históricas e mesmo um estudo filológico mais aprofundado quanto ao surgimento da expressão da sociedade civil, já que não é esse o intuito deste artigo, buscar-se-á apresentar um conceito simples e direto de sociedade civil, bem como, quando começa a ser usada essa expressão no Brasil apresentando a importância para a consolidação da democracia, passando de um modelo puramente representativo e imperfeito, para algo mais maduro, que seja condizente a uma sociedade organizada e unida por ideais comum, este pensamento pode parecer por vezes utópico, mas é possível perceber que o grau de maturação da sociedade, principalmente no Brasil, tem evoluído gradativamente.

Inicialmente deve-se conceituar o que seria a Sociedade Civil, essa expressão como reiteramos acima, tem as característica de ser bastante antiga, e somente passa a ser estruturada, 


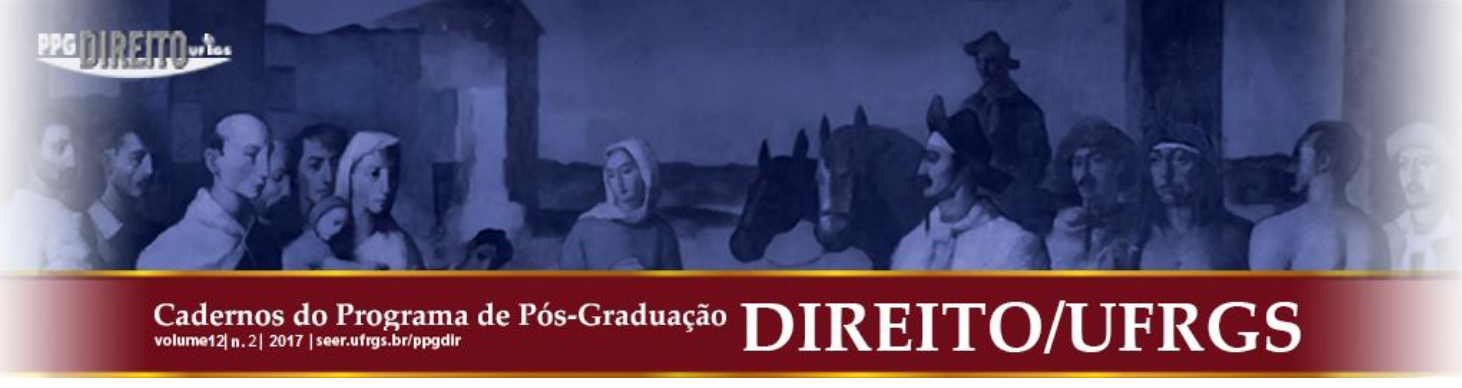

deveria ser feito de maneira cooperativa, principalmente porque ambos são bastantes heterogêneos e interconectam-se.

No Brasil, a expressão sociedade civil, aparece inicialmente nos anos de 70, durante o regime militar, para indicar principalmente a organização de pessoas que lutava de forma resistente e emblemática contra o regime militar. Assim percebe-se que a sociedade civil ocupou inicialmente no Brasil uma posição política-estratégica, e buscava a participação da sociedade nas instituições do Estado, na luta conta os autoritarismos deste. Francisco Weffort elucida-nos sobre a sociedade civil nesse contexto:

\begin{abstract}
Nós queríamos uma sociedade civil, precisávamos dela para nos defender do Estado monstruoso à nossa frente. Isso significa que, se não existisse precisaríamos inventala. Se fosse pequena precisaríamos engrandece-la. Não havia lugar para excessos de ceticismos, pois eles só tornariam os fracos ainda mais fracos (...) Numa palavra, nós precisávamos construir a sociedade civil porque queríamos a liberdade. (WEFFORT, 1988, apud COSTA, 1997, p. 13).
\end{abstract}

Nesse primeiro momento, em razão de um regime que restringia liberdades, a sociedade civil e o Estado, adquirem papéis antagônicos e representam interesses distintos, sendo que um busca a consolidação de direitos e uma redemocratização, e o segundo tenta-se manter no poder. A sociedade civil era basicamente composta inicialmente por sindicatos e união de estudantes.

Essas diferenças e antagonismos geram três perspectivas. A primeira concebe a sociedade civil como uma esfera de luta de classes e a democracia como espaço em construção sobre uma análise contra hegemônica (Coutinho), a segunda concebe a sociedade civil como espaço das representações populares e a democracia entendida corresponderia a uma renovação cultural (Chauí), a terceira vai entender a sociedade civil como uma arena de formação de demandas por direitos, funcionando como base fundadora da verdadeira democracia (corrente a que filiamo-nos, defendido por Weffort).

Após a redemocratização com a Constituição de 1988, e a consolidação de direitos individuais e sociais, a sociedade civil, deixou de ter uma função antagônica com o Estado, e passou a atuar de forma solidária, de forma combinada, ou mesmo atuando quando este se encontra ausente e não cumpre sua função pública de viés constitucional. Desta forma, surge o terceiro setor formado principalmente por Organizações da Sociedade Civil, Fundações, Entidades Filantrópicas, dentre outras que passam a ter grande uma grande atuação no Brasil, porém sem ainda ter uma influência política condizente com sua representatividade, o que pode prejudicar o ideal de democracia participativa.

Cadernos do Programa de Pós-Graduação em Direito PPGDir./UFRGS | Edição Digital | Porto Alegre | Volume XII | Número 2 | 2017 | P. 257 - 280 


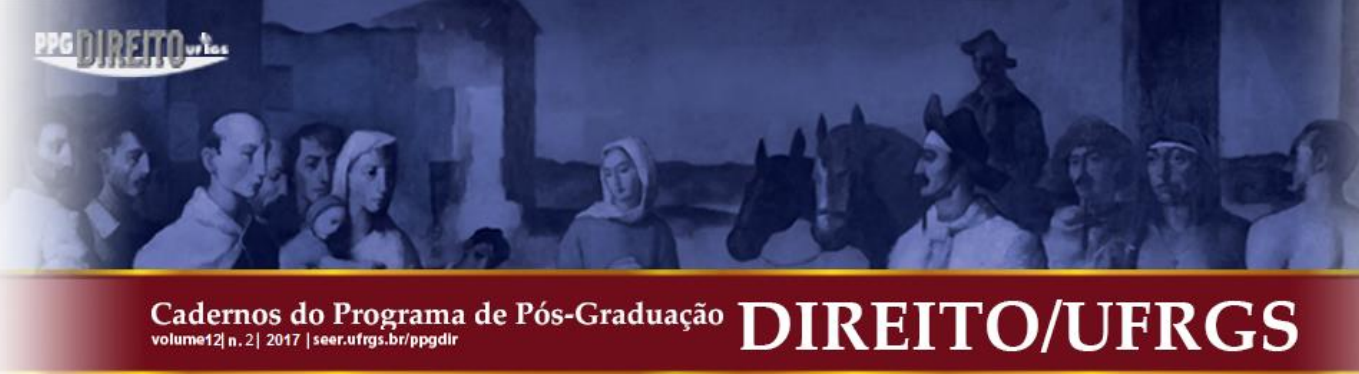

Muito embora, a Constituição de 1988, tenha previsto, vários modos de participação democrática da sociedade civil na democracia, seja no processo legislativo, por meio de referendo, plebiscito ou proposta de iniciativa popular, e nos tribunais superiores como STF, por meio da figura do amicus curie, esses meios ainda estão enviesado de bastantes restrições o que impossibilita o verdadeiro exercício da democracia, que acaba por ficar presa nas mãos de uma "sociedade política"(no sentido estrito).

Assim, existe uma tendência no Brasil, principalmente após os últimos anos, em que a sociedade civil, parece tentar se dissociar da sociedade política, e passar a atuar com maior independência, pleiteando uma maior participação dentro do corpo democrático do Estado. E nesse ponto chega-se a ideia principal do estado, analisar se seria possível a participação da sociedade civil de forma direta ou indireta na composição do Supremo Tribunal Federal, e apresentar os efeitos disso para a democracia Brasileira.

\section{ANÁLISE COMPARADA}

Para um enriquecimento maior do trabalho, e aprofundamento do formato da composição das Cortes Constitucionais, é de bom alvitre entender um pouco sobre o modelo adotado em outros países latino-americanas, que também utilizam o sistema civil law, entre esses apresentaremos nesse artigo de forma sintética, os casos da Argentina, Bolívia e Chile, sem esgotar o tema, que pode ser utilizado em futuros artigos a tratar deste assunto.

\subsection{Argentina}

No caso da Argentina o tribunal, que exerce o papel similar ao STF, seria a Corte Suprema de Justicia de la Nácion, órgão de cúpula do poder judiciário, com uma estrutura e modelo de justiça constitucional, mais próximo da ideia norte-americana, já que não se fala nesse país em controle concentrado ou abstrato de matéria constitucional, ao menos de forma direta, o que não excluí a função desse tribunal quanto ao controle de constitucionalidade.

$\mathrm{Na}$ Argentina, o modelo de investidura dos ministros de sua corte suprema, se assemelha em grande parte ao brasileiro e norte-americano, na qual o ministro é indicado pelo Presidente da República, após tem que passar por um processo de aprovação por 2/3 do Senado. Porém, 


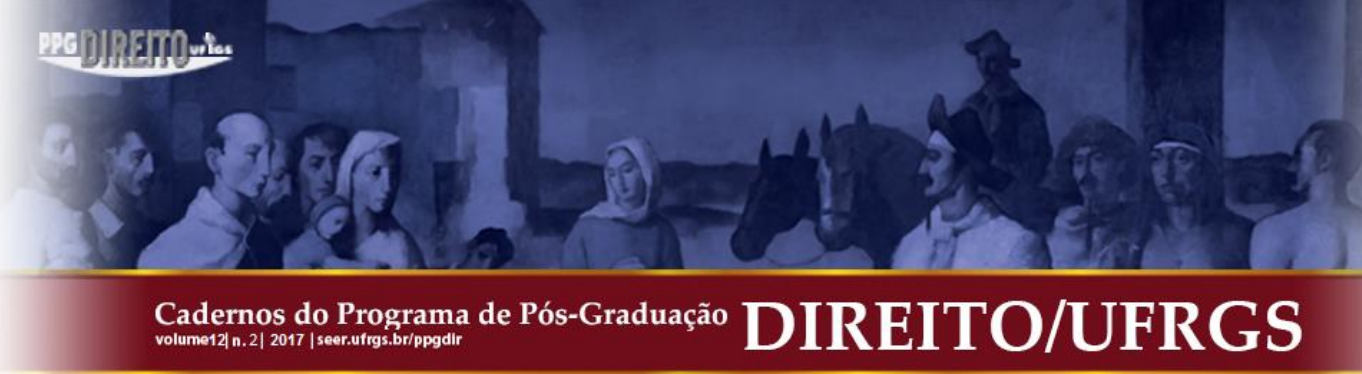

quando tratamos de requisitos para pleitear a vaga de ministro da corte, são um pouco mais objetivos do que no caso brasileiro, em razão de que é necessário ter exercido a advocacia por 8 anos, estar no gozo de seus direitos políticos.

Outro fato de relevante viés a se comentar, trata-se de que em razão de um Decreto Presidencial de 2003, todos os candidatos que pleiteiam uma vaga, ou seja, apontados para a Corte, devem passar por um período razoável de exposição pública, com intuito de dar mais transparência ao processo, e possibilitar uma maior participação da sociedade.

Contudo, embora a Argentina já tenha um procedimento que possibilite maior participação da sociedade civil, ainda possuem um problema e um debate polêmico, que trata principalmente quanto à independência dos membros da Corte Suprema, vale citar os doutrinadores Manili e Alfonsín que tratam da matéria:

(...) O Desprestígio que sofre na atualidade o Poder Judiciário em geral deriva, em grande medida, da falta de independência que a Corte Suprema de Justiça da Nação demonstrou ao longo dos últimos 50 a 60 anos. Mais especificamente, poderíamos situar o marco do começo da deterioração de sua independência no juízo político do promovido em 1946 pelo Presidente Juan Perón aos membros da Corte que não respondiam a ele, para substituí-los por juízes que tinham afinidade com sua política ideológica. (MNILI; ALDONSÍN, 2003, p. 535).

Assim, percebe-se que mesmo na Argentina, ainda persiste um caráter bastante político na composição do membros de sua Suprema Corte, o que coloca em uma posição de semelhança com os mesmos fatos que acontecem no caso do Supremo Tribunal Federal Brasileiro, em que permeia-se a dúvida na sociedade em geral, a mesma questão quanto a independência de seus membros.

\section{2 Bolívia}

Desde a Constituição de 1994, a Bolívia tradicionalmente um país caracterizado por um sistema civil law, já tinha em sua estrutura um Tribunal Constitucional, que após a reforma mais recente da Constituição, passou-se a chamar Tribunal Constitucional Plurinacional, com intuito de além de realizar o controle concentrado de maneira abstrata, deveria representar os diversos povos (nações) que compõem a Bolívia, protegendo assim seus direitos fundamentais, e tendo mais legitimidade em suas decisões. 


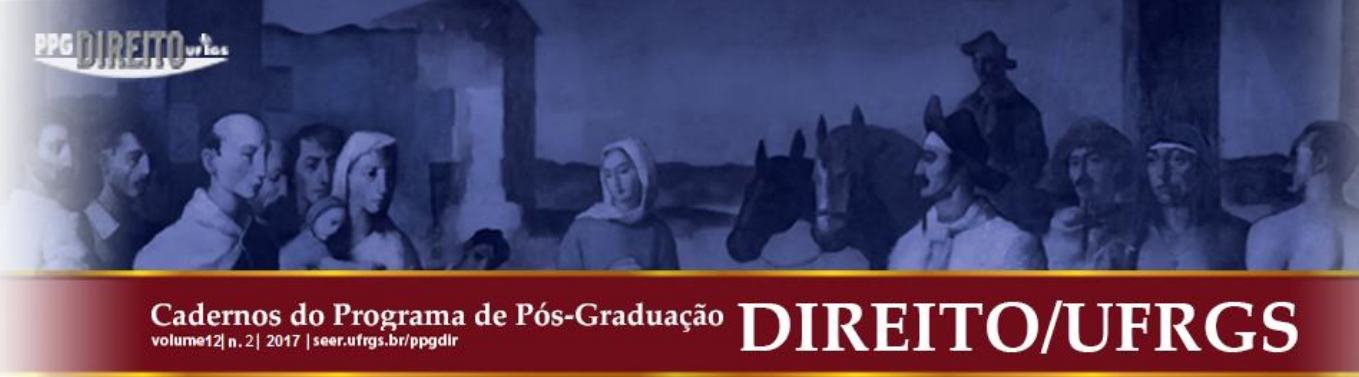

Em razão dessa plurinacionalidade, a composição do tribunal constitucional, é escolhido mediante o sufrágio universal com participação de todos os povos que compõem a Bolívia, como estabelece o artigo 197 da Constituição Plurinacional da Bolívia.

Além da escolha por meio do sufrágio universal, a proposição do candidato ao cargo de magistrado do tribunal, pode ser proposta por meio de Organizações da Sociedade Civil e das nações, e povos indígenas. O que demonstra uma abertura para a participação social gigantesca que foi propiciada pela constituição de 2009.

Entretanto, existem alguns critérios, a serem obedecidos para que uma pessoa possa ascender ao Tribunal Constitucional, deve ter 35 anos, e especialização acadêmica ou experiência de oito anos, nas áreas de Direito Constitucional, Administrativo e Direitos Humanos, bem como preencher os requisitos gerais para ser servidor público. Os Ministros nesse caso exercerão a função por $10 \operatorname{anos}^{4}$, não sendo permitida sua recondução ao cargo.

Sem um olhar enviesado, e despido de preconceitos, para analisar esse modelo de composição do Tribunal Constitucional, percebe-se que em tese propiciaria uma maior participação de toda a sociedade civil bolivariana, mesmo questionando-se algumas práticas governistas. Porém, o sufrágio universal é algo difícil de realizar no Brasil pelas razões aludidas anteriormente, e a nosso ver não condiz com a função de contramarjoritária que uma corte constitucional deve ter, mesmo que adquira maior legitimidade. Entretanto, a possibilidade de proposição de magistrados por organizações da sociedade e os requisitos objetivos de formação voltada na área constitucional e de direitos humanos, representa um grande avanço de critérios.

\subsection{Chile}

O Chile, assim como a grande maioria dos países da América Latina, passou, por um logo período ditatorial, e um lento processo de redemocratização que somente se concluí com a reforma constitucional de 2005, que teve grandes efeitos até mesmo para o seu Tribunal Constitucional, quanto ao processo de composição.

\footnotetext{
${ }^{4}$ No caso o mandato de um ministro ser restrito à um prazo de 10 (dez) anos, é algo interessante a se pensar, principalmente quando paramos para pensar no caso brasileiro em que a vitaliciedade permite que um ministro esteja no cargo desde 1989 e termine seu mandato apenas em 2020 como no caso de Celso de Mello. 


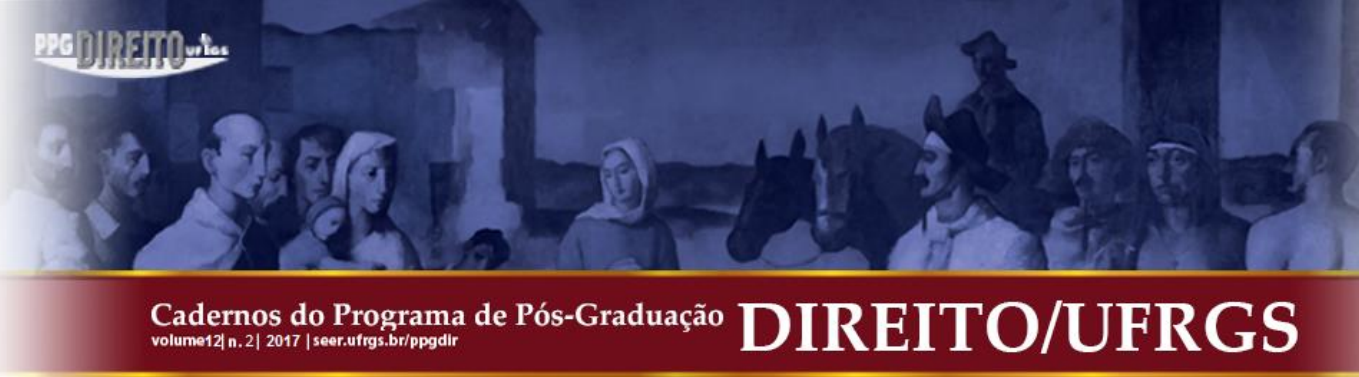

O Tribunal Constitucional Chileno vale ressaltar realiza tanto o controle a priori como a posteriori:

\begin{abstract}
Tal tribunal exerce inclusive controle preventivo sobre projetos de reformas constitucionais. Este mesmo controle preventivo é também realizado com relação aos tratados ou convenções internacionais submetidos a aprovação do Congresso. No que diz respeito ao controle preventivo da constitucionalidade dos projetos de lei durante sua tramitação legislativa e das reclamações no caso de o Presidente da República não promulgar uma lei quando deva fazê-lo, isto é uma faculdade e não uma obrigação do Tribunal Constitucional. (BENITES, 2003, p. 272).
\end{abstract}

Quanto à composição do Tribunal Constitucional, esse é integrado por 10 ministros, sendo que três são de livre designação pelo Presidente da República, 4 são escolhidos pelo Congresso, sendo que 2 são nomeados pelo Senado após votação com quórum de $2 / 3$, e 2 sendo propostos pela Câmara de Deputados, os outros três são escolhidos pela própria Corte, através de votação secreta.

Como requisitos objetivos, é necessário que se tenha o título de advogado, ao menos por quinze anos, e se destacado na atividade profissional, acadêmica ou pública (subjetivo a nosso ver). Com isso percebe-se que no caso chileno, o procedimento de composição de sua Corte, possuí uma maior participação dos três poderes da república, entretanto, não há nenhuma menção, a uma participação da sociedade civil.

\title{
4 A POSSIBILIDADE DA PARTICIPAÇÃo DA SOCIEDADE CIVIL NA COMPOSIÇÃO DO SUPREMO TRIBUNAL FEDERAL
}

É pacífico o entendimento, de que em razão de sua natureza jurídico-política de Corte Constitucional a forma de composição do Supremo Tribunal Federal, deve ser diferenciada, dos demais órgãos do judiciário, principalmente porque muito mais do que apenas questões de Direito, estará na esfera de competência do Ministro, o julgamento do que se denomina "Questões de Estado", em razão da enorme repercussão política que uma decisão desse colegiado possuí, bem como se estará protegendo-se a supremacia da carta fundamental de direitos do Brasil, a Constituição Federal.

Em razão dos fatos alhures explanados, que demonstram a importância desta Corte Constitucional, é que se defende nesse artigo, uma democratização do processo de composição deste colegiado, que passa justamente, por uma maior participação de todos os poderes da 


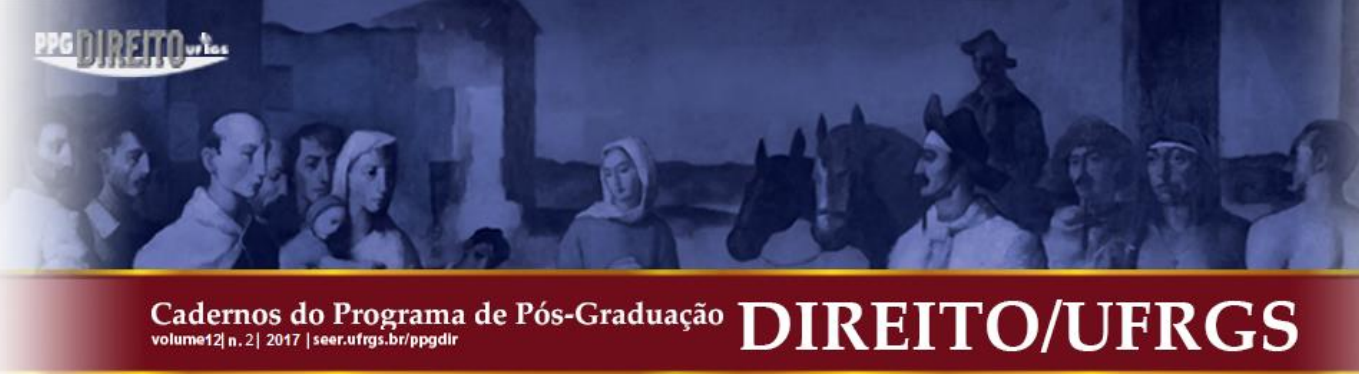

arbitrária nem prepotente, mas deve respeitar a minoria, então os compromissos passam a ser meios de convivência política." Com isso resolvemos a questão apresentada.

Após analisar essas problemáticas iniciais, passa-se a analisar, como a Sociedade Civil, poderia participar do processo de composição dos membros do STF. Primeiramente deveriam ser publicado de forma antecedente, os currículos dos prováveis candidatos ao cargo do STF, ficando disponível em uma página do Governo, durante um mês ou mais, antes da indicação pelo Presidente, possibilitando assim uma maior divulgação, para que as entidades pudessem assim se manifestar acerca do candidato, emitindo pareceres e notas que não seriam vinculantes, mas deveriam ser levadas em consideração, para que fosse possível a escolha do candidato ao cargo.

Segundo, seria ocorrer uma rodada de audiências públicas com os $\operatorname{cotados}{ }^{5}$ para que o mesmo apresentasse sua visão, essas audiências deveriam ocorrer dentro da $\mathrm{OAB}$, ou mesmo nas Faculdades de Direito em um número ao menos razoável que possibilite a maior participação possível. Esta convocação de audiência pública com os membros da sociedade civil poderia demonstrar e deixar mais claras o posicionamento do futuro ministro quanto questões pertinentes e polêmicas referentes à sociedade.

Terceira sugestão seria a possibilidade da exposição de motivos pelo responsável constitucional a indicação do ministro. Com isso, tentar-se-ia evitar uma escolha arbitrária e pessoal, já que seria necessária uma motivação das razões que levaram a indicação desse Ministro, o responsável teria que fazer uma defesa perante a sociedade do porque escolheu determinada pessoa.

Quarta sugestão é referente à sabatina do Senado Federal, que modernamente, tem funcionado apenas como uma forma de ratificação das escolhas do chefe do executivo, e uma forma de congratular o futuro ministro da corte constitucional. Então deveria ser alterado esse modelo, primeiro possibilitando uma participação de alguns órgãos selecionados da sociedade civil (a forma de escolha destes seria definido, por critérios de maior expressão nacional ou mesmo por sorteio, entre aqueles que se cadastrarem) durante a sabatina, bem como defende-

\footnotetext{
${ }^{5}$ Quando utiliza-se a palavra "cotado" no texto está se sugerindo, que os órgãos do Poder Judiciário, e as entidades da sociedade civil, recomendasse alguns nomes e currículos ao chefe do Poder Executivo responsável pela indicação final, e esse disponibilizasse ao debate nacional, esses que seriam os prováveis indicados ao cargo de Ministro do Supremo Tribunal Federal.
} 


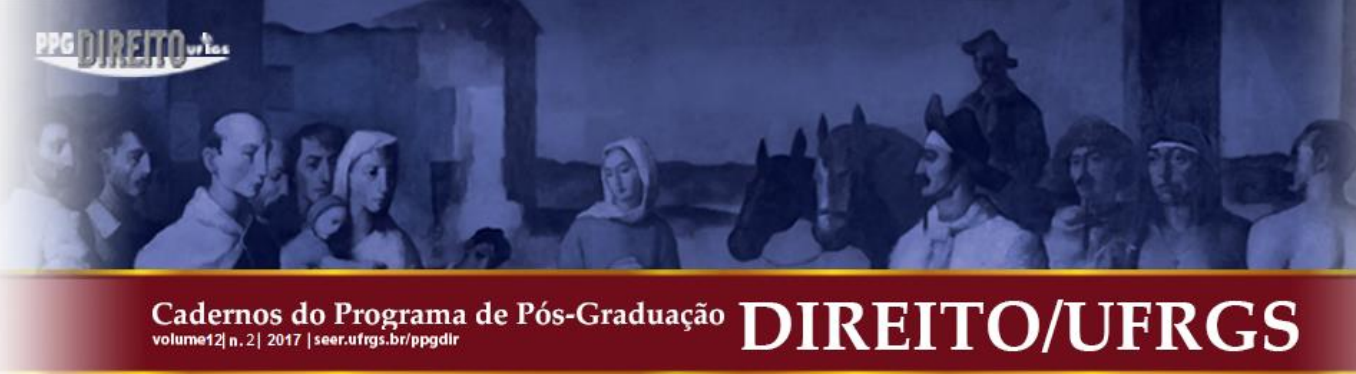

com uma abertura que permita a atuação da sociedade civil dentro das instituições políticas do país. O STF, embora funcione como à mais alta corte do judiciário brasileiro, possuí uma natureza política em razão principalmente de que suas decisões possuem repercussão geral, afetando a vida incontáveis pessoas, bem como se debruça diariamente com questões de política estatal e de direitos fundamentais.

Em razão dessa atuação ativista e política do Supremo Tribunal Federal, é que se entende que o atual procedimento de escolha e composição de seus Ministros pode ser considerada antidemocrática, em razão de que excluí a sociedade civil e o terceiro setor do debate político, e os diversos poderes da República, deixando a cargo quase que exclusivamente da atuação do executivo.

Com isso, busca-se corrigir tantos os procedimentos de escolha, bem como os requisitos constitucionais, que embora sejam considerados objetivos, demonstrou-se durante todo o decorrer do texto, que na verdade, são subjetivos e de caráter pessoal, desta feita, é necessário uma modificação constitucional, quanto a esse tema tratado nesse artigo, afim de propiciar os atuais conceitos de democracia moderna, possibilitando uma maior participação da sociedade civil, que deve agir sempre integrada com o Estado.

\section{REFERÊNCIAS}

ALEXY, Robert. "Balancing Constitutional Review, and Representation". International Journal of Consttutional Law, v. 3, n. 4, p. 572-581, 2005.

ALMEIDA, Eloísa Machado de. Sociedade civil e democracia: a participação da sociedade civil como amicus curiae no Supremo Tribunal Federal. São Paulo: Tese de Mestrado (Faculdade de Ciências Sociais da Pontifícia Universidade Católica de São Paulo), 2006.

AMARAL JÚNIOR, José Levi Mello do. "Proceso Constitucional no Brasil: nova composição do STF e mutação constitucional". Revista de Direito Constitucional e Internacional, v. 57, São Paulo, p. 100-108, 2006.

BRASIL. Constituição (1988). Brasília, DF: Senado Federal: Centro Gráfica, 2008. 


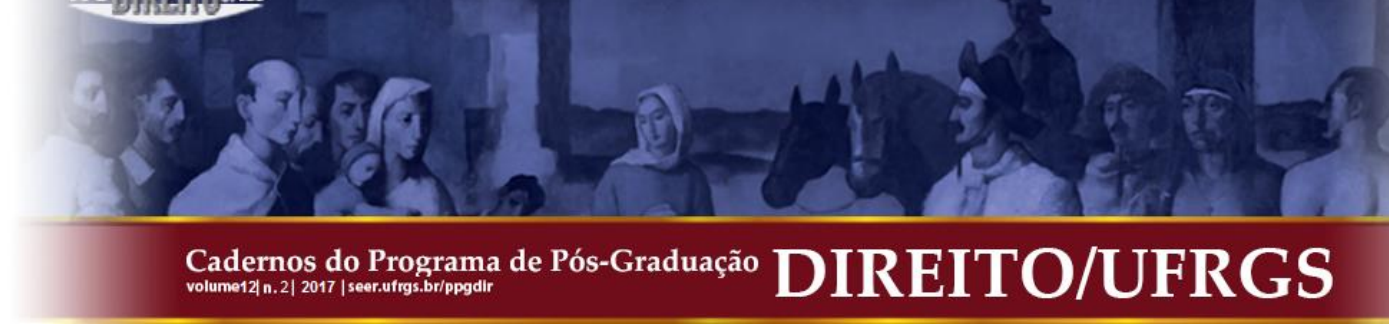

. Constituição da República dos Estados Unidos do Brasil, 1934. Disponível em: <http://www.planalto.gov.br/ccivil_03/constituicao/constituicao34.htm>. Acesso em 20 mar. 2017.

. Constituição dos Estados Unidos do Brasil, 1937. Disponível em: <http://www.planalto.gov.br/ccivil_03/constituicao/constituicao37.htm>. Acesso em 20 mar. 2017.

. Constituição dos Estados Unidos do Brasil, 1946. Disponível em: <http://www.planalto.gov.br/ccivil_03/constituicao/constituicao46.htm>. Acesso em 20 mar. 2017.

- Constituição da República Federativa do Brasil, 1967. Disponível em: http://www.planalto.gov.br/ccivil_03/constituicao/constituicao67.htm. Acesso em: 20 mar. 2017.

- Constituição da República Federativa do Brasil, 1988. Disponível em: <http://www.planalto.gov.br/ccivil_03/constituicao/ConstituicaoCompilado.htm>. Acesso em 20 mar. 2017.

BENITES, Gisela Maria Bester. O controle de constitucionalidade jurisdicional nos países do Mercosul e a amplitude democrática do acesso a justiça constitucional: analise comparativa no âmbito do direito processual internacional. Biblioteca jurídica virtual del Instituto de Investigaciones Juridicas de la UNAM. Disponível em: <http://www.juridicas.unam.mx/publica/librev/rev/dconstla/cont/2003/pr/pr13.pdf $>$. Acesso em: 10 mar. 2017.

CHILE. Tribunal Constitucional. Disponível em: <http://www.tribunalconstitucional.cl/>. Acesso em: 20 mar. de 2017.

COUTINHO, Carlos Nelson. A democracia como valor universal: notas sobre a questão democrática no Brasil. São Paulo: Ciências Humanas, 1980.

COSTA, Emília Viotti da. O Supremo Tribunal Federal e a construção da cidadania. 2. ed. São Paulo: UNESP, 2006.

COSTA, Sérgio. Categoria Analítica ou PassePartout Político-Normativo: notas bibliográficas sobre o conceito de sociedade civil. Bib - Revista Brasileira de Informação Bibliográfica em Ciências Sociais, Rio de Janeiro, n. 43, 1997.

DAGNINO, Evelina. Sociedade civil, espaços públicos e a construção democrática no Brasil: limites e possibilidades. In: DAGNINO, E. (Org). Sociedade Civil e Espaços Públicos no Brasil, São Paulo, 2002.

DURIGUETTO, Maria Lúcia. Sociedade civil e democracia - Um debate necessário. São Paulo: Cortez, 2007. 


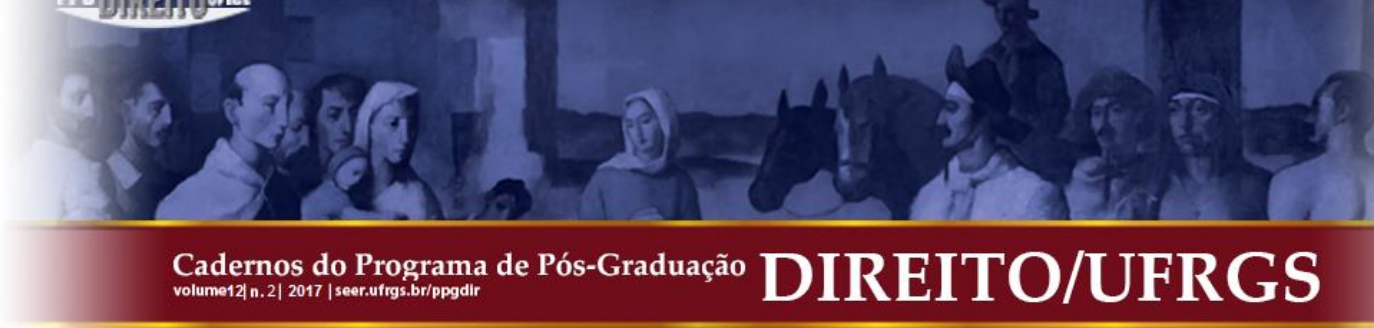

FAVOREAU, Louis. As Cortes Constitucionais. São Paulo: Landy Editora, 2004.

FERRAZ, Anna Candida da Cunha. A Projeção da Democracia Participativa na Jurisdição Constitucional no Brasil: As Audiências Públicas e sua Adoção no Modelo Concentrado de Constitucionalidade. São Paulo: Quartier Latin, 2011.

FONSECA, Ricardo Marcelo; FONSECA, Angela Couto Machado; RODRIGUES, Luana Liliane Hubner da Silva. Democracia e Heterotipia: uma Análise do Espaço Democrático. Cadernos do Programa de Pós-Graduação em Direito - PPGDir./UFRGS, Porto Alegre, v. 9, n. 2, dez. 2014. Disponível em: <http://seer.ufrgs.br/index.php/ppgdir/article/view/52336/32653>. Acesso em: 13 out. 2017.

FIX-ZAMUDIO, Héctor. Breves reflexiones sobre la naturaleza, estructura y funciones de los organismos jurisdiccionales especializados en la resolución de procesos constitucionales In: Revista Latino-Americana de Estudos Constitucionais, Belo Horizonte, n.1, p. 77-112, jan-jul. 2003.

GARCIA DE ENTERRIA, Eduardo. La Constitución como norma y el Tribunal Constitucional. 3. ed. 4. reimp. Madrid: Civitas, 1983.

GRAMSCI. Cadernos do cárcere. Tradução de Carlos Nelson Coutinho. v. 2. Rio de Janeiro: Civilização Brasileira, 2000.

HABERMAS, Jürgen. Direito e Democracia: entre a facticidade e validade. v. II. Rio de Janeiro: Tempo Brasileiro, 1997.

KIERECZ, Marlon Silvestre. A Crise da Democracia Representativa no Brasil. Cadernos do Programa de Pós-Graduação em Direito - PPGDir./UFRGS, Porto Alegre, v. 11, n. 2, dez. 2016. Disponível em: <http://seer.ufrgs.br/index.php/ppgdir/article/view/61967/39965>. Acesso em: 15 out. 2017.

MANILI, Pablo L. ALFONSÍN, Marcelo A. Lopez. Quién debe ejercer el control de constitucionalidade em Argentina? In: BAZÁN, Victor (Coord.) Defensa de la Constitución: garantismo e controle: libro em reconocimiento al Doctor J. Bidart. Buenos Aires: Ediar, 2003.

MENDES, Conrado Hubner. Controle de Constitucionalidade e Democracia. 1. ed., São Paulo: Campus Elsevier, 2007.

NOGUEIRA ALCALÁ, Humberto. Justicia y Tribunales constitucionales em América del Sur. Caracas: Jurídica Venezolana, 2006.

RAIS, Diogo. A sociedade e o Supremo Tribunal Federal: o caso das audiências públicas. Belo Horizonte: Fórum, 2012.

SILVA, Marilia Montenegro. Jurisdição Constitucional no MERCOSUL. Observatório da Jurisdição Constitucional, Brasília: IDP, Ano 4, p. 1-19, 2010/2011. 


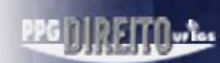

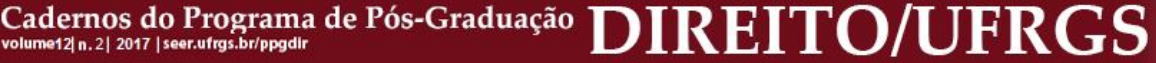

VIANNA, F. J. Oliveira. Instituições Políticas Brasileiras. v. 2. São Paulo, Edusp/Itatiaia.

Submissão: 28/04/2017

Aceito para Publicação: 20/10/2017 
